\title{
LINGUOCULTURAL FEATURES OF BRITISH TALES
}

\author{
Mariana Karanevych \\ Ternopil Volodymyr Hnatiuk National Pedagogical University, Ternopil, Ukraine \\ karanevych.m@gmail.com
}

\begin{abstract}
The paper examines linguocultural features of British tales. The relevance of the study is determined by great interest of linguistic science to the issues of national and cultural specificity of folk texts, which is caused by peculiarities of historical development, beliefs, traditions and customs of native people. The objective of the study is to reveal national and cultural characteristics of the British tales by means of their linguocultural analysis. This paper is divided into three sections. The first section analyses linguocultural specificity of the British folk tales. These texts are characterised by the abundance of colloquial words, violation of grammar rules, and prevalence of simple sentences. Among the most frequently used stylistic means are graphons, parallel constructions, repetition, and inversion. We have also revealed male gender preference in folk tales. The second section examines linguocultural features of the British literary tales. They are characterised by the variety of lexical and stylistic means and a diversity of characters and plots. These tales reflect individual worldviews of writers and their aesthetic tastes. The third section gives an overview of adaptation of traditional stories to modern times. Retellings of classic stories appear to meet the needs of people of different ages or population strata, to satisfy the demand for emerging trends or to come alive on screen. Both types of tales express cultural peculiarities of the British people, describe their lifestyle, surrounding and world outlook. The results of the investigation can be effectively used for a further profound comparative analysis of sociolinguistic and linguocultural features of English, Scottish, Welsh and Irish tales.
\end{abstract}

Keywords: linguocultural analysis; worldview; folk tales; literary tales; stylistic means; grammar; adaptation.

\section{Introduction}

In the process of globalisation that inevitably leads to mixing up cultures, it is of vital importance to save national and cultural identity. Not to disappear in a melting pot of nationalities, one should know more about his/her roots. The wisdom of the British people, their world outlook, traditions, and beliefs are expressed in tales. Nowadays these traditional stories are widely used in English language learning process. Thus, Bocharnikova and Eremina (2017) claim that "a travel to the land of fairy tale" is an effective unconventional form of training, which makes it possible to introduce integrated lessons by means of combination of teaching literature and English. At the same time, Gómez (2010) discusses the ways of teaching grammar and vocabulary in the meaningful context provided with the story. A recent review of the literature found that linguists have an interest in the understanding of lexical, grammatical, stylistic, and cognitive aspects of British tales. For instance, Nazarenko (2015) focuses on proper names in fairy tales, Petrova (2015) draws our attention to traditional lexico-stylistic formulae in folk tales, and Solodova (2015) describes their cognitive characteristics. Meanwhile, tales are used as a way to introduce students to the British culture. Constantinescu (2016) insists on the usage of translational strategies and techniques that render the cultural dimension of the source text in order to give the young readers access to a foreign culture. Translation of British tales has been investigated by scholars all over the world: Hurenko (2015) analyses the peculiarities of Ukrainian translation, Rojas-Lizana (2013) highlights the problem of handling of the grammatical and sexual gender in Spanish translation, Głuszak (2013) points out the drawbacks of the existing Polish translations of British tales. In recent years there has been a growing interest in the interdisciplinary approach to investigations in linguistics. However, few researchers have addressed the issue of linguocultural features of the British tales. Due to this, the aim of the paper is to reveal national and cultural peculiarities of the British tales by means of their linguocultural analysis. To achieve this goal, we tried to solve the following tasks: 1) to reveal linguocultural specificity of the British folk tales; 2) to investigate linguocultural features of the British literary tales; 3) to study modern adaptations of traditional tales. The material of our analysis was based on the British literary tales by L. Carroll, R. Kipling, O. Wilde and folk tales. In general, the paper is an account of results of the empirical study.

\section{Methods applied}

In the process of investigation, the following research methods were used: linguistic observation and analysis to reveal linguocultural peculiarities of tales and their relations with history, religion, material and spiritual values of the British people, comparison and generalisation to define isomorphic and allomorphic features of folk and literary tales. 


\section{Results and Discussion}

\section{British Folk Tales}

According to Oxford Advanced Learner's Dictionary of Current English, a folk tale is "a very old traditional story from a particular place that was originally passed on to people in a spoken form" (Wehmeier, 2000, p. 458). A folk tale reflects the experience of a people, its mode of life, beliefs, customs, and world outlook. That is why an investigation of folk tales allows tracing of mutual influence of the British language and culture.

Due to the fact that folk tales had an oral form of presentation, they are full of colloquialisms and graphons which are used to reflect authentic pronunciation: "Well, I'll e'en do as thou wishest" (The Three Wishes, n.d.). Usually there are some grammar mistakes in the speech of common men, which explains their appearance in the analysed texts: "Suppose you and our daughter was to be married, and was to have a son, and he was to grow up, and was to come down into the cellar to draw the beer, and the mallet was to fall on his head and kill him" (Jacobs, 1892o, p. 11).

As for the typical syntactic features, inversion is frequently used in folk tales: "So he took the cow's halter in his hand, and off he started" (Jacobs, 1892e, p. 60), "But the bannock dodged round about, and off it went" (The Wee Bannock, n.d.), "Off he went as fast as the wind <...>" (The King of England and His Three Sons, n.d.). Parallel constructions make the process of narration easier. They can be found both in folk and literary tales: "He gave a pull, but it stuck, and she gave a pull, but it stuck, and they both pulled till they had nigh pulled the nose off, but it stuck and stuck" (The Three Wishes, n.d.), "The Dog was wild, and the Horse was wild, and the Cow was wild, and the Sheep was wild, and the Pig was wild-as wild as wild could be - and they walked in the Wet Wild Woods by their wild lones" (Kipling, 1902c). Names of characters in folk tales often consist of two parts: a common name and a rhyming word, for example, Henny-penny, Cocky-locky, Goosey-poosey, Turkey-lurkey, Foxy-woxy (Jacobs, 1892b, p. 113-117).

The framing device is often used in traditional storytelling. The episode when children ask their grandmother to tell them a tale: "Grannie, grannie, come tell us the story of the wee bannock" (The Wee Bannock, n.d.) is a bright illustration of 'a tale within a tale'. The nested narrative was also revealed in Wilde's story "The Devoted Friend" (1994, p. 60-86).

On average, the main character of folk tales is brave, sly, witty, and sociable. Some characters are heroes or heroines of a few tales. For example, the Sleeping Beauty: " $<\ldots>$ and sees a beautiful princess lying full stretch on a gold bedstead, fast asleep" (The King of England and His Three Sons, n.d.), "<... he fell down dead asleep upon a bench in the hall. The king and queen tried all they could do to wake him up, but all in vain" (Jacobs, 1892i, p. 38) or Jack: "There was once upon a time a poor widow who had an only son named Jack < ..>”" (Jacobs, 1892e, p. 59), "To make my long story short, I shall follow poor Jack $<\ldots>$ " (The King of England and His Three Sons, n.d.), "Then Jack got a good meal and bed, and in the morning he and the King went on to the fields" (Jacobs, 1892d, p. 87). In general, gender balance in folk tales is somewhat broken. Thus, in the analysed texts a family usually gets bigger due to the birth of a boy: " $<\ldots>$ at last a baby-boy came to the queen" (Jacobs, 1892i, p. 33); "There was an old man and an old woman, and they had one son" (Jacobs, 1892d, p. 81), “< $<>$ out comes the young wife to meet him with a fine jolly, bonny young son, and they all lived happy ever afterwards" (Jacobs, 1892d, p. 92). In the tale "The History of Tom Thumb" a woman dreams about a son too: "I should be the happiest creature in the world if I had a son" (Jacobs, 1892k, p. 141).

Folk tales are often full of magic owing to appearance of the following magic creatures: a fairy (The Three Wishes, n.d.), a magician (Jacobs, 1892k), and an ogre (Jacobs, 1892e). Among the magic means used in tales there are beans: "Ah! You don't know what these beans are, if you plant them over-night, by morning they grow right up to the sky" (Jacobs, 1892e, p. 60), golden apples: "< ...> the old king fell very sick one time and there was nothing at all that could make him well but some golden apples from a far country" (The King of England and His Three Sons, n.d.), or even a tobacco box: "< $<>>$ drew the little box out. And when he opened it, out there hopped three little red men, and asked Jack: 'What is your will with us?"' (Jacobs, 1892d, p. 83).

The symbolic number in folk tales is 3 . The analysis showed that the girl can guess the name of Tom Tit Tot three times a day: "I'll give you three guesses every night to guess my name, and if you haven't guessed it before the month's up you shall be mine" (Jacobs, 1892q, p. 4), the ghost of a wife answers her husband thrice: "All withered and wasted away" (Jacobs, 18921, p. 139), three times the Baron tries to escape from his doom (Jacobs, 1892j, p. 190-195), rescuers need to go round a hill thrice saying magic spells (Jacobs, 1892a, p. 120). Moreover, a threefold repetition expresses duration of an action: "So they went along, and they went along, and they went along < ...>" (Jacobs, 1892b, p. 115), "They fought, and they fought, and they fought $<\ldots>$ " (Jacobs, 1892a, p. 123). A sevenfold repetition is used to emphasise a very long-lasting 
activity: "So Jack climbed and he climbed and he climbed and he climbed and he climbed and he climbed and he climbed till at last he reached the sky" (Jacobs, 1892e, p. 62).

English folk tales depict the way people lived in England hundreds of years ago. Thus, the characters of a tale "The Wee Bannock" (n.d.) live in a thatched house. A spinning-wheel in the tale "Tom Tit Tot" is a symbol of hard work of common people (Jacobs, 1892q, p. 3). A rocking chair is a traditional household item in the English home (Jacobs, 1892c, p. 26). A chimney symbolises not only a homely home, but it is also the safest place in a house: "And away went the wife to the parlour chimney, and she pulled the rag with the ten pounds in it from the parlour chimney <...>" (Jacobs, 1892f, p. 41). Folk tales also depict everyday activities of ordinary people: "The old man looked after the cows, and the old wife span on the distaff", "<...> there was a weaver sitting at the loom, and the wife winding a clue of yarn", "The goodwife was stirring the soup, and the goodman plaiting sprit-binnings for the cows" (The Wee Bannock, n.d.). Much attention in the analysed texts is paid to money, precious stones and metals (Jacobs, 1892a,1892c, 1892f, $1892 \mathrm{~m}$ ), but for common people livestock is much more valuable than finances (Jacobs, 1892g, 1892n). A traditional English dish pudding is often mentioned in folk tales: "Titty Mouse made a pudding and Tatty Mouse made a pudding, so they both made a pudding" (Jacobs, 1892p, p. 77), "I wish I'd a good link of black pudding here before me" (The Three Wishes, n.d.), "A short time afterwards his mother was making a batter-pudding < ...> (Jacobs, 1892k, p. 142). The English housewives also baked oatmeal bannocks as a good snack for ale (The Wee Bannock, n.d.).

Folk tales also give insight into the history of Great Britain. In the UK execution by beheading was used in the past. This way of punishment is mentioned both in literary and folk tales: "The Queen had only one way of settling all difficulties, great or small. 'Off with his head!' she said, without even looking round" (Carroll, 1998, p. 125), " <...> he sent immediately for the headsman to behead his youngest son, who was taken away there and then in a carriage" (The King of England and His Three Sons, n.d.), "When the queen saw him she was in a rage, and said he should be beheaded" (Jacobs, 1892k, p. 146).

Religion is an important aspect of life in Britain. Thus, people follow the tradition of blessing before leaving a house and "try to keep the Sunday holy" (Jacobs, 1892d, p. 82, 91), the queen refuses to christen her baby till the king's arrival (Jacobs, 1892i, p. 33). We can also trace reference to angels in folk tales (Jacobs, $1892 \mathrm{~m}$, p. 74). The episode, when the King of Elfland revives Childe Rowland's brothers, reminds us of the resurrection: "With this he anointed the ears, eyelids, nostrils, lips, and finger-tips of the two brothers, and they sprang at one into life, and declared that their souls had been away, but now returned" (Jacobs, 1892a, p. 124).

Interestingly, folk tales often contain violence to highlight points of moral value, which may be too scary for children. For example, suitability of such tales as "Mr Fox" (Jacobs, 1892h) and "The Golden Arm" (Jacobs, 1892l) for this audience is doubtful. It can be explained by the fact that originally "fairy tales were for adults. Children listened to them and enjoyed them, but children were not the primary audience" (Gaiman, 2016).

As for the end of a folk tale, it is often unpredictable. Surprisingly, only a small number of tales have happy endings as in the following example: "Jack and his mother became very rich, and he married a great princess, and they lived happy ever after" (Jacobs, 1892e, p. 67). Some of them end tragically: "He fell dead on the ground where he stood, and the spider suck'd every drop of his blood" (Jacobs, 1892k, p. 146), or left uncertain so that the readers can only guess about the fate of characters: "Jubal, seeing such a nice carriage, thought something, and did not like to say No, and said Yes, and pointed up the tree; and they told him to come down immediately, as there was a young lady in search of him "' (The King of England and His Three Sons, n.d.).

\section{British Literary Tales}

The research has revealed that an author's tale has a more diverse vocabulary and grammar than a folk tale. The choice of words and sentence structures in literary tales depend on the individual style of a writer, his/her aesthetic taste, and worldview. As we analysed the works of outstanding representatives of the British culture, it was possible to disclose the ways of its reflection in literature.

In the process of reading "Alice's Adventures in Wonderland", one can get to know more about realia of the British society. Thinking about the sea, Alice mentioned "bathing machines" (Carroll, 1998, p. 23). These roofed and walled wooden carts were used in Britain in the 18th and 19th centuries, because bathing suits were not considered proper clothing in which to be seen. In addition, usually the English house has a name, not a number, or you can read the surname of its resident on a door-plate. That is why when Alice came upon a neat little house she saw a bright brass plate with the name ' $W$. RABBIT' engraved on it (Carroll, 1998, p. 42). As far as a fireplace is considered to be a symbol of domestic warmth, such lexical items as chimney (Carroll, 1998, p. 45, 50, 51, 94), hearthrug (Carroll, 1998, p. 16) and fender (Carroll, 1998 , p. 16) are used in description of the interior. The British tradition of tea drinking is depicted in the chapter "A Mad Tea-Party" where the Hatter was present. It is worth pointing out that the origin of the English saying "Mad as a hatter" derives from mercury poisoning of hat-makers. One of the characters of 
"Alice's Adventures in Wonderland" is the Dormouse. The rodent which is native to the British Isles is nocturnal, so this character is constantly sleeping all through the day. In the analysed tale Carroll also mentioned some real personalities of Great Britain: William the Conqueror, Edwin and Morcar (the earls of Mercia and Northumbria), Stigand (the patriotic archbishop of Canterbury) (Carroll, 1998, p. 30-31).

Education is of vital importance for the British people. Thus, to check if she is all right, Alice recites poems "How doth the Little Busy Bee" (I. Watts) (Carroll, 1998, p. 62), "You are Old, Father William" (Carroll's parody of R. Southey's poem "The Old Man's Comforts and How He Gained Them") (Carroll, 1998, p. 62), "Tis the Voice of the Lobster" (L. Carroll's parody of I. Watts' poem "The Sluggard") (Carroll, 1998, p. 157). The main heroine at the age of seven is proud of her knowledge of such 'hard words' as longitude and latitude (Carroll, 1998, p. 5). The erudition of the girl is proved by the statement that "Alice had never been in a court of justice before, but she had read about them in books, and she was quite pleased to find that she knew the name of nearly everything there" (Carroll, 1998, p. 163). There are bookshelves even in the interior of a rabbit hole (Carroll, 1998, p. 3).

Cultural peculiarities of the British tales reveal themselves in the usage of words of wisdom. Thus, when the King forbids the Cheshire Cat to look at His Highness, Alice answers with a proverb: "A cat may look at a king" (Carroll, 1998, p. 125), which means that even a person of low status or importance has rights.

World-famous British politeness and etiquette also attract attention of foreign readers of "Alice's Adventures in the Wonderland": "< ...> and she tried to curtsey as she spoke" (Carroll, 1998, p. 5), "I beg your pardon!" (Carroll, 1998, p. 25, 26, 31, 38, 176), "And who is Dinah, if I might venture to ask the question?" (Carroll, 1998, p. 39), "they both bowed low" (Carroll, 1998, p. 78), "all of them bowed low" (Carroll, 1998, p. 113). Reserve, which is considered to be a typical trait of character of the British people, is inherent to characters of this tale too: "Let this be a lesson to you never to lose your temper" (Carroll, 1998, p. 39), "Keep your temper" (Carroll, 1998, p. 62). A love of cleanliness and order can be traced to the times when primitive people lived in caves and the Woman told her Man: "Wipe your feet, dear, when you come in, and now we'll keep house" (Kipling, 1902c).

The British are known to be very conservative. They keep their traditions and convey from one generation to the next. Among the most pleasant of them is Christmas gift exchange: "I'll give them a new pair of boots every Christmas" (Carroll, 1998, p. 16). The target audience of "Alice's Adventures in the Wonderland" gets to know about one of the traditional English dishes - Mock Turtle Soup that was created in the mid-18th century as a cheaper imitation of green turtle soup (Carroll, 1998, p. 137). Orange jam (Carroll, 1998, p. 4) and tarts (Carroll, 1998, p. 162) are mentioned in the analysed tale too. Carroll describes also types of entertainment that were popular among the British people in the past: croquet "Alice thought she had never seen such a curious croquet-ground in her life <...>" (Carroll, 1998, p. 121) and quadrille "The Lobster Quadrille" (Carroll, 1998, p. 147).

Comparisons in tales reveal peculiarities of the world outlook of people living in the UK. For example, Russia is associated with coldness and snow " $<\ldots>$ and she (Russian Princess) was as pale as the Snow Palace in which she had always lived" (Wilde, 1994, p. 86), beauty - with flowers "She was like a white rose before, but she is like a red rose now" (Wilde, 1994, p. 86), "His hair is dark as the hyacinth-blossom and his lips are red as the rose of his desire <...>" (Wilde, 1994, p. 32), glint in the eyes - with diamonds "Her eyes are bright as diamonds" (Kipling, 1902a).

Number 3 is one of the most symbolic numbers in the British literary tales as well as in folk tales: there are three rose-bushes in the garden (Wilde, 1994, p. 36); the Nightingale sings thrice "of the birth of love in the heart of a boy and a girl", "of the birth of passion in the soul of a man and a maid", "of the Love that is perfected by Death" (Wilde, 1994, p. 40-42); the Horse, Dog and Ox are three animals that serve humanity (Kipling, 1902b); the punishment for an idle Camel is three extra days of work (Kipling, 1902b); the Cat strikes three bargains with the Woman, the Man, and the Dog (Kipling, 1902c); the Woman praises the Cat three times " <...> if I say three words in your praise, you may drink the warm white milk three times a day for always and always and always" (Kipling, 1902c). Threefold repetition is often used to emphasise the points the writers want to accentuate for a target audience: "Romance is dead, Romance is dead, Romance is dead" (Wilde, 1994, p. 94).

The main character of "The Nightingale and the Rose" is typical of the British tales: young, attractive, and clever. But he is too pragmatic: "It (Love) is not half as useful as Logic, for it does not prove anything $<\ldots>$ ", "<... it is quite unpractical, and, as in this age to be practical is everything, I shall go back to Philosophy and study Metaphysics" (Wilde, 1994, p. 44). The Student embodies the satire on the people of the UK, whose life is usually orderly and disciplined. Pragmatism of characters can also be revealed in their understanding of friendship: " $<\ldots>$ he might ask me to let him have some flour on credit, and that I could not do. Flour is one thing, and friendship is another, and they should not be confused" (Wilde, 1994, p. 66). Wilde disapproves such relations among people and appeals to high feelings. 
In their literary works writers express their points of view on different aspects of social life. Thus, Wilde laughs at odd English laws that are to regulate the phenomena which are out of human being's control: "We must really issue a proclamation that birds are not to be allowed to die here" (Wilde, 1994, p. 28). The object of Carroll's ridicule is politicians who are often engaged in some absurd activity. This is depicted in the caucusrace episode when animals were running around in circles to get dry (Carroll, 1998, p. 29-41). It is worth mentioning that the embodiment of a politician is a mouse which gives hollow promises. It uses such "big words" as conduct, insolence, usurpation not knowing their meanings just to look wise (Carroll, 1998, p. 32).

\section{The British Tales Reconsidered}

In the epoch of multiculturalism, the concept of political correctness influenced such spheres as media, politics, and medicine. In everyday speech, we become more careful in the choice of words not to hurt the feelings of people of different age groups, national backgrounds, races, and sexual minorities. But the main message from Garner (1994) in his "Politically Correct Bedtime Stories" is that there is a time and a place for everything. The book is a collection of well-known tales rewritten by the author to bring them into accordance with the trend of political correctness. Let's take a closer look at the British tales that were subjected to the experiment: "The Three Little Pigs", "Goldilocks", and "Jack and the Beanstalk". The author of experimental tales uses politically correct animal language: a nonhuman animal and an animal companion for "a pet" (Garner, 1994b). To ensure the protection of animal rights, Garner even adds a note: "No actual wolves were harmed in the writing of the story" (Garner, 1994c). The lexical items wommon and womyn (Garner, 1994a) are used instead of "a woman", and "the English man" is substituted with the English person (Garner, 1994b) to avoid sexism and gender bias. The author used the term melanin impoverished to define light-skinned people, because of his awareness about colourism (Garner, 1994a). Sizeism is condemned in a modern retelling of "Jack and the Beanstalk" (Garner, 1994b). Following the trend of political correctness, the words "fool" and "idiot" were substituted with differently abled (Garner, 1994b). Garner used the phrase excluded from the normal circle of economic activity instead of "poor" to avoid socioeconomic status discrimination (Garner, 1994b). Taken as a whole, this word choice is not the result of political correctness, but a satire on it. Every lexical item has its natural context, out of which it sounds absurd.

In our fast moving world traditional British tales are not forgotten. They are adapted to entertain modern children. Thus, Dinosaurs cooked chocolate pudding instead of cereal in "Goldilocks and the Three Dinosaurs" by Willems (2012). Still, the story ends with a morale-allusion to the original tale: "If you ever find yourself in the wrong story, leave". Nowadays the Chinese language and culture are growing in popularity worldwide. Due to this demand, there appeared a tale "Goldy Luck and the Three Pandas" by Yim (2014). In this retelling Goldy Luck visits the Chan family consisting of three pandas to share turnip cakes before the Chinese New Year. Instead, this little girl eats their congee and turns their house into a bear garden.

Classic stories are also adapted to meet the demands of young adult readers. "Alice's Adventures in Wonderland" (Carroll, 1998) inspired Meyer (2016) to write the novel "Heartless" and Oakes (2016) to publish a trilogy "Queen of Hearts". A folk tale "Jack and the Beanstalk" gave birth to a modern retelling "The World Above" by Dokey (2010). These adaptations are characterised by a rich vocabulary, the use of diverse stylistic devices and a multilayered plot.

To further our research we intend to analyse how plots of traditional tales are employed in cinematography. Thus, such films as "The Hunger Games" and "Jack the Giant Slayer" echo the plot of tales "Jack and the Beanstalk" and "Jack the Giant Killer", "Coraline" resembles the story of "Alice in Wonderland".

\section{Conclusions}

To sum up, our study provides an insight into the British culture. The British tales reflect national peculiarities of the British people, their traits of character, world outlook, religion and beliefs. Both types of tales describe the following realia: everyday way of life, the interior of dwellings, favourite dishes and drinks. The investigation proves that a symbolic number both in literary and folk tales is 3 . A typical positive character of the analysed stories is a young handsome man, who overcomes a lot of difficulties to achieve his aim.

For a long time folk tales spread only by word of mouth, that is why the simplicity of their form was very important. Simple sentences often prevail over composite ones. Folk tales are also characterised by the abundance of colloquial words and violation of grammar rules. This can be explained by the fact that their main characters are usually common people. Among the most frequently used stylistic means are graphons, parallel constructions, repetition and inversion. In addition, it was revealed that gender balance in folk tales is somewhat broken because of male gender preference. All in all, the simplicity of a form does not affect the profound meaning of folk tales: they make us think about values, educate both children and adults. 
According to the results of the research, a literary tale is characterised by the variety of lexical and stylistic means and a diversity of characters and plots. This type of tales reflects an individual worldview of a writer, who is a representative of the British culture but has his own life experience and aesthetic taste.

Traditional literature is timeless. This is proved by the fact that classic tales gain a renewed momentum to meet the needs of modern society. They are adapted for people of different ages or population strata to satisfy the demand for emerging trends or to come alive on screen.

\section{References:}

Bocharnikova, A.S. \& Eremina, S.A. (2017). Fairy Tales at Secondary School English Lessons. Philological Class, 48 (2), 57-62.

Carroll, L. (1998). Alice's Adventures in Wonderland. Chicago, Illinois: VolumeOne Publishing.

Constantinescu, M. (2016). Translating Children's Stories - Reflections and Practices [E-Reader Version]. Retrieved November 8, 2017 from http://www.scielo.br/scielo.php?script=sci_arttext\&pid=S2175-79682016000100155

Dokey C. (2010). The World Above. New York: Simon Pulse.

Gaiman, N. (2016). The View from the Cheap Seats: Selected Nonfiction [E-Reader Version]. Retrieved November 6, 2017 from https://books.google.com.ua

Garner, J.F. (1994a). Goldilocks. In Politically Correct Bedtime Stories [E-Reader Version]. Retrieved July 22, 2017 from https://www.yumpu.com/en/document/view/29219123/politically-correct-bedtime-stories-james-finn-garner

Garner, J.F. (1994b). Jack and the Beanstalk. In Politically Correct Bedtime Stories [E-Reader Version]. Retrieved July 22, 2017 from https://www.yumpu.com/en/document/view/29219123/politically-correct-bedtime-stories-james-finn-garner

Garner, J.F. (1994c). The Three Little Pigs. In Politically Correct Bedtime Stories [E-Reader Version]. Retrieved July 22, 2017 from https://www.yumpu.com/en/document/view/29219123/politically-correct-bedtime-stories-james-finn-garner

Głuszak, J. (2013). Dated Translations of Rudyard Kipling's "The Cat that Walked by Himself". Przektadaniec. A Journal of Literary Translation, 22-23, 161-175.

Gómez, A.B. (2010). How to Use Tales for the Teaching of Vocabulary and Grammar in a Primary Education English Class. Resla, $23,31-52$.

Hurenko, M.A., Hurenko, P. A. \& Derkach, T.P. (2015). Some peculiarities of translation of English fairy-tales. Yunyy ucheniy, $2,22-24$.

Jacobs, J. (1892a). Childe Rowland. In English Fairy Tales (pp.117-125). New York, London: G.P. Putnam's Sons.

Jacobs, J. (1892b). Henny-Penny. In English Fairy Tales (pp.113-117). New York, London: G.P. Putnam's Sons.

Jacobs, J. (1892c). How Jack Went to Seek His Fortune. In English Fairy Tales (pp.24-28). New York, London: G.P. Putnam's Sons. Jacobs, J. (1892d). Jack and His Golden Snuff-Box. In English Fairy Tales (pp.81-93). New York, London: G.P. Putnam's Sons. Jacobs, J. (1892e). Jack and the Beanstalk. In English Fairy Tales (pp.59-68). New York, London: G.P. Putnam's Sons.

Jacobs, J. (1892f). Jack Hannaford. In English Fairy Tales (pp.40-44). New York, London: G.P. Putnam's Sons.

Jacobs, J. (1892g). Mr Vinegar. In English Fairy Tales (pp.28-33). New York, London: G.P. Putnam's Sons.

Jacobs, J. (1892h). Mr Fox. In English Fairy Tales (pp.148-152). New York, London: G.P. Putnam's Sons.

Jacobs, J. (1892i). Nix Nought Nothing. In English Fairy Tales (pp.33-40). New York, London: G.P. Putnam's Sons.

Jacobs, J. (1892j). The Fish and the Ring. In English Fairy Tales (pp.190-195). New York, London: G.P. Putnam's Sons.

Jacobs, J. (1892k). The History of Tom Thumb. In English Fairy Tales (pp.140-148). New York, London: G.P. Putnam's Sons.

Jacobs, J. (18921). The Golden Arm. In English Fairy Tales (pp.138-140). New York, London: G.P. Putnam's Sons.

Jacobs, J. (1892m). The Master and His Pupil. In English Fairy Tales (pp.73-77). New York, London: G.P. Putnam's Sons.

Jacobs, J. (1892n). The Old Woman and Her Pig. In English Fairy Tales (pp.20-24). New York, London: G.P. Putnam's Sons.

Jacobs, J. (1892o). The Three Sillies. In English Fairy Tales (pp.9-15). New York, London: G.P. Putnam's Sons.

Jacobs, J. (1892p). Titty Mouse and Tatty Mouse. In English Fairy Tales (pp.77-81). New York, London: G.P. Putnam's Sons.

Jacobs, J. (1892). Tom Tit Tot. In English Fairy Tales (pp.1-9). New York, London: G.P. Putnam's Sons.

Kipling, R. (1902a). How the Alphabet Was Made [E-Reader Version]. Retrieved November 12, 2017 from http://etc.usf.edu/lit2go/79/just-so-stories/1303/how-the-alphabet-was-made/

Kipling, R. (1902b). How the Camel Got His Hump [E-Reader Version]. Retrieved November 12, 2017 from http://etc.usf.edu/lit2go/79/just-so-stories/1301/how-the-camel-got-his-hump/

Kipling, R. (1902c). The Cat That Walked by Himself [E-Reader Version]. Retrieved November 12, 2017 from http://etc.usf.edu/lit2go/79/just-so-stories/1296/the-cat-that-walked-by-himself/

Meyer, M. (2016). Heartless. New York: Feiwel \& Friends.

Nazarenko, O.V. (2015) Polyaspects of proper names in English fairy tale discourse and their communicative aspect. Modern linguistic systems as instruments of the reality transformation, 7, 9-10. https://doi.org/10.18007/gisap:ps.v0i7.936

Oakes, C. (2016). Queen of Hearts. New York: HarperTeen.

Petrova, E.E. (2015). Traditional Lexico-Stylistic Formulae in English Folk Tales (Comparisons and Repetitions). International Research Journal, 7 (38), Part 4, 58-60.

Rojas-Lizana, I., Hannah, E. (2013). Handling of the Grammatical and Sexual Gender in the Spanish Translation of a Story by Oscar Wilde. Babel - Revue Internationale De La Traduction - International Journal of Translation, 59 (3), $310-331$. https://doi.org/10.1075/babel.59.3.04roj

Solodova, E. (2015). Linguistic and Cognitive Characteristics of the Composition of the Text of J.K. Rowling's English Tales. Advances in Language and Literary Studies, 6 (5), 151-156. https://doi.org/10.7575/aiac.alls.v.6n.5p.151

The King of England and His Three Sons (n.d.). [E-Reader Version]. Retrieved July 16, 2017 from http://www.sacredtexts.com/neu/eng/meft/meft29.htm

The Three Wishes (n.d.) [E-Reader Version]. Retrieved July 16, 2017 from http://www.sacred-texts.com $/ \mathrm{neu} / \mathrm{eng} / \mathrm{meft} / \mathrm{meft} 23 . \mathrm{htm}$

The Wee Bannock (n.d.) [E-Reader Version]. Retrieved July 16, 2017 from http://www.sacred-texts.com/neu/eng/meft/meft 15.htm

Wehmeier, S. (Ed.). (2000). Folk tale. In Oxford Advanced Learner's Dictionary of Current English (6 ${ }^{\text {th }}$ ed.). Oxford: Oxford University Press.

Wilde, O. (1994). Fairy Tales. Kamensk-Shakhtinski, Russia: Stanitsa Publishers.

Willems, M. (2012). Goldilocks and the Three Dinosaurs. New York: Balzer + Bray.

Yim, N. (2014). Goldy Luck and the Three Pandas. Watertown, Mass.: Charlesbridge. 